\title{
Research on the Negative Spillover Effect of Scandal Type on National Image in Product-harm Crisis
}

\author{
Hai Ri \\ School of Management, Shanghai University, 20 Cheng Zhong Road, Shanghai 201800, China
}

\begin{abstract}
When a product-harm crisis occurs in a multinational company, the negative spillover effect is likely to be larger than a country, affecting the national image of the country of origin and other brands of the country. The results of our study showed that consumers' personality characteristics or way of thinking content could moderate the spillover effect of brand scandal on the country image. Specifically, for the consumers with analytic thinking, ability (vs. morality) brand scandal had greater impact on country image; for the consumers with holistic thinking, morality (vs. ability) brand scandal had greater impact on country image. Moreover, this moderation was mediated by consumers' sense of predictability. The research conclusion can bring certain enlightenment and thinking to enterprises, which is more conducive to enterprises to establish accurate contact with consumers and formulate more effective marketing strategies.
\end{abstract}

Keywords: National image; Spillover effects; Brand scandal; Thinking mode

DOI: $10.7176 / \mathrm{JESD} / 10-16-14$

Publication date: August $31^{\text {st }} 2019$

\section{Introduction}

In recent years, domestic and foreign product-harm crisis events occur frequently, on the one hand, hurt the interests of consumers; On the other hand, it will cause economic losses to enterprises. In addition to adverse effects on related enterprises, product-harm crisis may even affect the industry and even the whole society when it is serious. Product-harm crisis also often leads to product recall, which may have a significant impact on the company's reputation, sales and financial value. With the increasing pressure of the market environment, the dissemination of media information is gradually transparent, and negative events of brands have emerged in major newspapers and media networks, causing strong repercussions among the public. It hurts brand equity and brand trust, and also reduces consumers' evaluation of the brand and purchase intention. Emerging brand scandals not only cause great damage to a single brand, but also may affect consumers' perception of the national image of the country where the brand is located.

As brand internationalization becomes a hot topic in academic circles, the research on spillover effect should also be extended to the influence of the negative events of multinational brands on the national image of the country of origin and other brands of the country of origin. Negative spillover effects in 2000 after it has received more and more academic attention, gradually become the brand negative events an important branch in the research field of the brand scandal negative spillover effect mechanism and regulation of variables that exist, but most of the research is still limited in a certain country or a single consumer under the background of thinking, in fact, with the acceleration of international economic integration, more and more companies and brands promote the globalization strategy, manufacture and sale of their products in multiple countries. When a product-harm crisis occurs in a multinational company, the negative spillover effect is likely to be larger than a country, affecting the national image of the country of origin and other brands of the country. However, brand scandals spillover effects of country of origin image, academia has not yet been paid close attention to, in addition to the brand characteristics and properties of negative events information two key factors, in the country of origin image in the perspective of literature, the basic character of the individual consumers as not to affect factors to study, thus inspired me to explore consumer personality or way of thinking on the country of origin of national image has adjust the spillover effect.

In the past, some scholars have studied the spillover effect of brand scandals, often discussing the impact of brand scandals on other brands, alliance brands, competitive brands and even the whole industry in the brand portfolio, but few studies have involved the impact on the national image of the country of origin. Therefore, the purpose of this study is to explore the spillover effect of brand scandal on the national image of the country of origin and the moderating effect of the content of consumer thinking mode under the product-harm crisis.

\section{Theoretical Background}

\subsection{Brand scandal}

In recent years, a variety of brand scandals have emerged one after another. These scandals not only affect the brand itself, but also the whole industry and even the whole country. For example, the melamine scandal of SanLu milk powder has greatly affected other brands in the domestic milk powder industry. The Siemens "refrigerator door" affair has tarnished Germany's national image. Brand scandals can lead to negative emotions among 
consumers and greatly reduce their evaluation of brands. Therefore, it is of practical significance to study the influencing mechanism of brand scandals. Brand scandal refers to events that have great negative impact on the brand due to the lack of brand products, services, social responsibilities, etc. (Menon Getal, 1999). Generally speaking, the spread of brand scandal is relatively extensive, and will bring negative impact to the brand. Research in this field includes brand scandals, product injury crises, negative exposure events, corporate disasters, etc. (Dean, 2004; Dawar, 2000; Sundaram, 1999; Jorgensen, 1994).

Many scholars have classified brand scandals from different perspectives. From the perspective of corporate motivation, Pullig (2000) divided brand scandals into product/service related and organization related. Negative events related to products/services refer to problems in the quality of products/services, which may cause consumers to doubt the ability of products/services; Organization-related brand scandals are often related to ethical or ethical issues, leading consumers to suspect that brands have poor motives. Celso and Ricardo divide brand scandals into product attribute and corporate value. Similarly, Pullig et al. (2006) divide brand scandals into performance-related and value-related types. Performance-related brand scandal refers to the scandal events related to the functional attributes of products, such as the recall of automobile parts. Value-related brand scandals refer to social or ethical events, such as racial discrimination, illegal pollution, environmental pollution, etc.

After the occurrence of brand scandals, consumers will attribute the causes of brand scandals from different aspects. Coombs (2007) divided product injury incidents into three categories: victimization type, negligence type and intentional type. On this basis, duan guimin et al. (2012) divided brand scandals into two types: negligent and intentional. The fault type refers to the brand scandal events caused by objective factors such as technology and ability. Deliberate type refers to the product or service quality defects caused by the "bad intention" of the brand.

\subsection{National image}

National image is a concept put forward by foreign scholars in the research of country of origin effect. According to Nagashima, who put forward this concept earlier, national image refers to the impression, reputation and stereotype of a country's products by business people and consumers. This image is created by the combination of products, national characteristics, economic and political background, history and tradition. Bilkey and Nes defined national image as the general cognition of a country's products derived from consumers' general impression of a certain country. Roth and Romeo believe that national image refers to consumers' overall perception of products from a certain country based on their perception of the advantages and disadvantages of its products and marketing. Martin and Eroglug defined national image as the sum of a person's descriptive, inferential and informational beliefs about a country. To sum up, this study believes that national image is consumers' overall perception of a country and its products.

According to the elaborationlikelihood model (ELM) put forward by social psychologists Petty and Cacioppo, the consumer information office will carry out two routes: the Central Route; One is Peripheral Route. When consumers have the motivation and ability to process information, consumers process information through the central route. When consumers cannot have both, and there are edge clues, consumers process information through edge lines..

In the research on country of origin effect, there are two important findings: country of origin information plays an important role in the product evaluation of consumers, especially when there is lack of other aspects of product information; Compared with the study on country-of-origin effect under the condition of single-cue, under the condition of multiple-cue, the country-of-origin effect is somewhat reduced. The possible explanation for this is that even if consumers have an incentive to buy products, when they have little information about other aspects of the products, they can only tend to the information processing of marginal lines. In this way, the national image as marginal clues may affect consumers' purchasing intentions. The empirical study conducted by Johansson, Ronkainen and Czinkota on Russian tractors sold in the United States confirms this point. In the model they proposed, country image as a marginal clue influences the core process of product evaluation through country of origin evaluation. According to the consistency theory of cognition, consumers like equilibrium psychologically. If they feel unbalanced psychologically, they will feel uneasy or depressed psychologically. Heider argues that if there is an imbalance between attitudes, it is necessary to change the original attitudes in order to restore the balance. He first assumed that there was a ternary relationship between "myself", "others" and "objects", in which people would try their best to avoid the unbalanced state and maintain the equilibrium state. Therefore, consumers' cognition and attitude towards the national image will affect their cognition and attitude towards products from the country, and ultimately affect their purchasing intention. Klein, Ettenson and Morris proposed the Animosity Model of Foreign Product Purchase based on the investigation of Nanjing, China, and found that Chinese consumers' hatred of Japan was negatively correlated with their intention to buy Japanese products, and this effect was independent of their judgment of Japanese Product quality. This finding is a good example of the consistency theory. Fishbein and Ajzen argue that there are three types of beliefs: descriptive, inferential, and informational. These beliefs are formed in different ways. Descriptive beliefs are based on direct first-hand experience of the relevant product; Informational beliefs are based on indirect second hand experience; Inferential beliefs are beliefs 
that go beyond given information (primary and secondary) and are based on past experiences related to current stimuli.

\subsection{Brand evaluation}

Consumers' evaluation of the brand is of great significance to the brand. On the financial level, consumers with higher evaluation of the brand are more inclined to buy the brand's products and services. Better reputation is also the intangible property of the brand. At the market level, brands with higher evaluation generally have better market performance, which is usually reflected in the performance indicators of market share and market competitiveness.

Many scholars have explored the composition of brand evaluation. Aaker (2009) proposed the evaluation from five aspects: brand loyalty, leadership, differentiation, cognition and market behaviour. Dahlen (2006) thinks that brand evaluation includes five aspects: comprehensive brand evaluation, brand trust, ideal brand, brand purchase intention and brand choice. Osgood (2014) conducted brand evaluation from the aspects of comprehensive brand evaluation and purchase intention. Tian min (2014), a Chinese scholar, explored the effect of CSR on brand evaluation, in which the measurement of brand evaluation refers to the studies of Dahlen, Osgood, Schiffman and others, including three dimensions of comprehensive brand evaluation, brand trust and purchase intention, with a good generalization. This research mainly studies the response of consumers in the context of brand scandal. Brand evaluation should be consumer-centered. Combined with the research on brand evaluation and the reality of this research, the relationship between brand, country of origin and consumers is highlighted.

\subsection{Thinking mode of consumers}

Thinking mode is a kind of thinking habit of people to process information and perceive the world around, and it is a relatively fixed metacognitive mode formed under the long-term influence of national culture. Nisbett et al. have a comprehensive and profound understanding of the holistic and analytic thinking mode. They summarized the Oriental's view of the world as integration, change and contradiction. The western logical thinking is characterized by rejecting compromise, keeping consistent and free from contradiction. Based on this, Nisbett et al. hold that different social and cultural environments form different individual cognitive processes: complex social and cultural environments encourage individuals to pay attention to the connection between the overall background and things; The simple social and cultural environment urges individuals to separate things from the overall background and pay attention to things themselves. Therefore, it puts forward two different ways of individual thinking, namely holistic thinking and analytic thinking. It argues that Oriental society tends to holistic thinking, and people pay more attention to the surrounding environment or situation, emphasize the correlation between objects and situations, and make explanations and predictions of things based on this correlation. Western society tends to analytic thinking, and people pay more attention to the attributes of the object itself, separate the object from the situation, and judge and recognize the object based on principles and categories.

Thinking mode has not only been developed in the study of ethnic cultural differences, but also has been studied in detail at the individual level, that is, the bias of holistic thinking mode or analytic thinking mode is different. Cheek and Norem found that independent self-constructors tend to use analytic thinking, while interdependent self-constructors tend to use holistic thinking. Siebert and Kunz found that individual differences in thinking patterns would affect individual decision-making patterns. Epstein systematically analysed the characteristics of holistic and analytic thinking mode at the individual level, and believed that holistic thinking is easier to change, emphasizing passive experience, natural integration and feeling past events. Individuals with analytic thinking, on the other hand, tend not to change easily and place more emphasis on active experience, abstract integration, and evaluation of past events. The application of holistic analytic thinking in the field of consumer behaviour is one of the latest research hotspots. Consumers with different ways of thinking have different perceptions of information related to products and brands, and show different attitudes and behaviors.

\subsection{Spillover effect of brand scandals}

Studies on brand scandals generally follow the following two main lines: first, discuss the negative impact of brand scandals on the brand itself and which factors can dilute the above negative impact; Second, examine the spillover effects of brand scandals. This study focuses on the second main line. The spillover effect of a brand scandal is a phenomenon in which a brand scandal affects other entities that are related to it but have no negative events of their own. After reviewing previous literature, we found that the spillover effect of brand scandals mainly includes the following aspects: spillover effect on other brands in the brand portfolio, spillover effect on alliance brands, spillover effect on competitive brands in the same industry and even the whole industry (product category).

Based on the above analysis, it is still rare to consider the spillover effect of brand scandal on national image. Recently, researchers have begun to experiment in this field, only to discover that Brand Transgressions, such as Magnusson's, have a strong spillover effect on the national image and associated brands of the country in which the Brand is based. Moreover, this effect is regulated by the Prototypicality of the errant brand and the degree of 
development of the country where the errant brand resides.

\section{Negative Spillover Effect of Scandal Attribute on National Image}

3.1 Thinking mode of Consumers adjusts the negative spillover effect of scandal attribute on national image

As the subject of evaluation, the characteristics of consumers will also affect the spillover effect. Lee, Youn and Nayakankuppam (2011) found that thinking mode is an influential factor at the consumer level. Due to analytic thinking, consumers pay more attention to the event itself and less to the connection between situational information and things, so they are more likely to be affected by endogenous scandals and generate spillover effect on competitive brands. Holistic thinking consumers pay more attention to the situational factors of exogenous scandals and generate spillover effect on competitive brands. In addition, Tian Yang, Huang Yun Hui, Wang Haizhong and He Liu (2013) discussed that under the cross-cultural background, Oriental (or interdependent selfconstruction) consumers have greater negative spillover effect on competitive brands than western (or independent self-construction) consumers. This is because interdependent self-constructed consumers tend to use holistic thinking to focus on the links between events and situational factors, while independent self-constructed consumers tend to use analytic thinking to focus on the events themselves, so as not to overflow to competitive brands. For example, the occurrence of the powerful brand scandal in the German automobile industry has damaged consumers' original expectation of Germany's ability in product manufacturing and other aspects. Consumers with analytic thinking mode are more vulnerable to the impact of endogenous scandals, and their evaluation on the national image of the country is significantly reduced. In contrast, the ethical brand scandal in Germany did not conflict with consumers' original expectations of the country, so it did not have a significant impact on consumers' national image evaluation. Therefore, compared with the ethical brand scandal, the spillover effect of the analytic thinking mode of consumers on the power brand scandal is greater. The Dolce \& Gabbana ethical brand scandal in Italy has destroyed consumers' original expectations of Italy in sincerity, friendliness and other warmth for consumers with a holistic thinking. As a result, consumers' evaluation of Italy's national image is significantly reduced. On the contrary, analytic thinking consumers pay more attention to the D\&G event itself, which has little impact on Italy's national image evaluation. In conclusion, consumer thinking mode plays a moderating role in the negative spillover effect of scandal attribute on national image in product-harm crisis events: for the consumers with analytic thinking, ability ( vs. morality) brand scandal had greater impact on country image; for the consumers with holistic thinking, morality ( vs. ability) brand scandal had greater impact on country image.

\subsection{Mediating role of brand evaluation}

There is no doubt that the brand scandal will bring a series of negative effects. Brand scandals reduce consumer trust and therefore buy fewer branded products; Brand scandals can affect consumers' and brands' emotions; Brand scandals can affect consumer attitudes; After the occurrence of scandal, consumers will make a series of coping behaviors, etc. (Wang Xiaoyu et al., 2006; Zeng Wangming et al., 2008; Ahluwalia, 2013; Wang Lili et al., 2009). In the field of corporate image and country of origin effect, few empirical studies have investigated the impact of corporate image on national image. Some researches on regional brand only put forward from the qualitative Angle that the influence of corporate image on national image should arouse scholars' attention. For example, Dinnie argues that a country's businesses are decisive factors in its national brand. Dowling believes that there is a twoway relationship between corporate image and national image, that is, corporate image will not only be affected by national image, but also have an impact on national image. To sum up, once the occurrence of brand scandal violates consumers' original expectation, it will destroy consumers' perception of the brand, reduce their evaluation of the brand, and further affect consumers' evaluation of the national image. Therefore, in product-harm crisis, brand evaluation plays an intermediary role in the negative spillover effect of brand scandal attribute on national image.

\section{Discussion}

\subsection{Pay attention to the differences in the way consumers think}

The fundamental principles contained in the holistic and analytical ways of thinking are quite different. Cultural differences between China and the west also lead to the influence of thinking mode. Western thinking is analytical, emphasizing the identification of logical concepts and adhering to non-contradictory views. Eastern thinking is holistic, encouraging people to recognize change and accept conflict. Western thinking encourages the withdrawal of form from content in order to assess the validity of assertions. As a result, westerners avoid some of the logic mistakes that easterners make. Eastern thinking has produced more accurate beliefs about many aspects of the world and more appropriate explanations for the causes of human behavior. Oriental thinking emphasizes on the situational factors that affect things and human behaviors, and also requires people to realize the possibility of changes in the development process of things and individuals.

\subsection{Brand evaluation affects national image}


Brand evaluation plays an intermediary role in the type of brand scandal and the negative spillover effect on national image. In recent years, brand scandals have not only caused great damage to individual brands, but also may affect consumers' perception of the national image of the country where the brand is located. As we all know, as an old industrialized country, Germany has a rigorous and efficient image in the world's consumers' mind. The "refrigerator door" scandal at Siemens has not only raised concerns about the quality of German products, but also undermined Germany's national image. In contrast, the bribery case in China, which also happened to the Siemens brand, did not have a big impact on the national image of Germany, although many consumers criticized it. In the context of global economic integration, national image evaluation presents unprecedented challenges to enterprise crisis managers. The results of the empirical research in this paper can bring some enlightenment and thinking to enterprises, which is more conducive to enterprises to establish accurate contact with consumers, formulate more effective marketing strategies and prevent and deal with crises, so as to make the healthy development of national economy and trade.

\subsection{Test data of consumer thinking mode}

In the case of product-harm crisis, for consumers with analytic thinking mode, the negative spillover effect of power brand scandal on national image is greater than that of moral type. For consumers with holistic thinking mode, compared with power type, moral brand scandal has a greater impact on the negative spillover effect of national image. At the beginning of the product entry into the market, we will test the differences of consumers' ways of thinking and classify them. For brand scandal attributes of crisis events, enterprises can effectively solve the crisis according to the differences of consumers' ways of thinking and effectively reduce the cost of crisis management.

\subsection{Thinking mode leading solutions to the crisis}

By solving the communication mode of crisis, consumers can start their thinking mode of local processing and pay more attention to the key points matching their consumption mode. For integrated consumers, the solution strategy should pay more attention to the relevant factors of scene, environment and history, while for analytical consumers, the solution strategy focuses on the attribute characteristics of the object itself. Follow the understanding law of the way of consumer thinking, so as to reduce the negative spillover effect.

\section{References}

Chen, Y. , Ganesan, S. , \& Liu, Y. . (2009). Does a firm $\backslash$ "s product-recall strategy affect its financial value? an examination of strategic alternatives during product-harm crises. Journal of Marketing, 73(6), 214-226.

Dorresteyn, P. . (2007). The effects of negative publicity on consumer reactions: the moderating roles of loyalty and the degree to which consumers like a promotion. Tetrahedron Letters, 35(37), 3167-3170.

Pullig, C. , Netemeyer, R. G. , \& Biswas, A. . (2006). Attitude basis, certainty, and challenge alignment: a case of negative brand publicity. Journal of the Academy of Marketing Science, 34(4), 528-542.

Wojciszke, B. , Brycz, H. , \& Borkenau, P. . (1993). Effects of information content and evaluative extremity on positivity and negativity biases. Journal of Personality and Social Psychology, 64(3), 327-335.

Coombs, \& Timothy, W. . (2007). Protecting organization reputations during a crisis: the development and application of situational crisis communication theory. Corporate Reputation Review, 10(3), 163-176.

Hong-Yan, J. , Hai-Zhong, W. , Ke, Z. , \& Management, S. O. . (2014). The spillover effect of brand scandal on country image: the moderating role of country of origin stereotype content. Journal of Business Economics, $1(6), 55-64$.

Nagashima, A. . (1970). A comparison of japanese and u.s. attitudes toward foreign products. Journal of Marketing, 12(3), 7-8.

Martin, I. M., \& Eroglu, S. A. (1993). Measuring a multi-dimensional construct: country image. Journal of Business Research, 28(3), 191-210.

Al-Sulaiti, Khalid I., \& Baker, Michael J. (1998). Country of origin effects: a literature review. Marketing Intelligence \& Planning, 16(3), 150-199.

Chao, P. (1993). Partitioning country of origin effects: consumer evaluations of a hybrid product. Journal of International Business Studies, 24(2), 291-306.

Johansson, J. K., \& Ilkka A. Ronkainen and Michael R. Czinkota. (1994). Negative country-of-origin effects: the case of the new russia. Journal of International Business Studies, 25(1), 157-176.

Nisbett R E, Peng K, Choi I, et al. Culture and systems of thought: holistic vs[J]. Psychological Review, 2001, $108(2): 291$

Monga, A. B. , \& John, D. R. . (2008). When does negative brand publicity hurt? the moderating influence of analytic versus holistic thinking. Journal of Consumer Psychology, 18(4), 320-332.

Cheek, N. N., \& Norem, Julie K. (2016). Holistic thinkers anchor less: exploring the roles of self-construal and thinking styles in anchoring susceptibility. Personality \& Individual Differences, 115, S0191886916300356. 
Epstein, S. (2003). Cognitive-Experiential Self-Theory of Personality. Handbook of Psychology.

Dawar, N., \& Pillutla, Madan M. (2000). Impact of product-harm crises on brand equity: the moderating role of consumer expectations. Journal of Marketing Research, 37(2), 215-226. 